\title{
The Passive Constructions in Surat Al-An'am Verses: an Analytical Descriptive Study
}

\author{
Dr. Alaa Tarif Gharaibeh * \\ Lecturer at Language Center \\ World Islamic Sciences and Education University W.I.S.E \\ Amman/Jordan
}

\begin{abstract}
This study explores and analyses the passive voice constructions in the holy Quran in terms of their syntactic and semantic structures, as well as the functions they serve practically and rhetorically. Al-An'am Verses (The Cattle), which takes its name from vv. 136, 138 and 139 that refer to the beliefs of the idolatrous Arabs concerning the cattle (an 'am). Passivation in the holy Quran is a phenomenon worthy of research, due to the various functions it serves and the implication it incorporates. The analytical descriptive method was used, and results showed the occurrence of both agentive and agentless passive structures in Al-An'am, with different stylistic and rhetorical functions. Implications for future research are provided.
\end{abstract}

Keywords: Passivation, Agentive Passive, Agentless passive, Al-An'am Verses.

\section{Introduction}

Passivation encompasses a process of saturation, which saturates the external theta role, which is consigned to a variable bound by an existential operator by existential closure. The external argument is no longer syntactically accessible, except on the level of interpretation. Passivation relates to predicates that allow both an external and an internal theta role. The ability to assign an accusative case is withdrawn from the passive verb, and the internal argument moves to the subject position to receive a case. Manipulation of the theta grid is not incorporated in Passivation (Laks, 2009).

In Arabic, all kinds of active verbs can be transformed into a passive voice except the imperative, which is due to its inability to provide a complete meaning without its agent. In contrast to English, the passive voice in Arabic is essentially the product of a vowel change, which affects not only the phonology and morphology of the verb, but also the syntax and semantics of the verbal sentence (Alsuhaibani, 2012).

A substantial property specific to morphological passive constructions in Arabic is that inflections representing tense, aspect/mood and agreement are also affixed to the passivized verb, thus forming a verbal complex, while in periphrastic passive it is be that is inflected for such features. As far as Arabic is concerned, the passive verb is formed by what is so called passive melody, consisting of two vocalic affixes (specifically infixes) (Sormani, 2017).

Whatever their grammatical persuasion, early Arab grammarians agreed that the AP is a verb built for an object whose agent has not been named. The verb system of Standard Arabic shows features of non concatenative morphology where changes to the verb root define various morphological derivations by superimposing pattern templates to the root. One of the most relevant of these morphological operations is in fixation (Maalej, 1999). In general, the following rule represents Passivation in Arabic (Shormani, 2017, 89):

Active: V DP DP

\section{3}

Passive: 13 \# (Where symbol \# stands for the thematic subject that is deleted from the syntax)

This rule reveals that in Arabic, unlike English (and many other languages), the passive voice is not constructed through the use with passive auxiliary and passive participle, it is rather constructed through the altering vowels of the active verb (Jabbari \& Kafipour, 2011)

The passive in Arabic, which literally means "the unknown", as indicated through its name, is a verb whose agent is omitted due to some reason(s): the speaker does not know the agent, fears or hate him...etc. In comparison to agents in English passive sentences, which can be explicitly expressed, agents in Arabic passive sentences generally do not appear in surface structure, because in most cases, they are obligatorily deleted. 
However, some passive sentences in the holy Quran incorporate an overtly expressed agent. Thus Quran's passive sentences can be divided into two types, namely, (i) agentless passive sentences and (ii) agentive passive sentences. In a total number of 18.181 verbs in the Holy Qur'an, only 957 have the passive from (5.3\%), which indicates that active verbs are more basic than passive ones, and that they are more frequently used than passive verbs (Nofal, 2011).

\section{Agent less Passive Sentences}

On the light of the fact that Arabic does not usually permit the presence of the agent in the surface structure of the passive constructions, it is not surprising that most passive constructions in Surat Al-An'am are agentless. Agentless passive sentence is a passive construction that does not have an explicit agentive by-phrase, and where the suppressed agent is either (i) unspecified or (ii) can be uniquely implicit in the context in which the passive structure occurs. Thus, agent less passive constructions in the sample of the current study occur more than agentive passive constructions. The following are illustrative examples:

(Messengers before you were ridiculed, but those who mocked them became besieged by what they ridiculed. (AI-An'am: 10).

(many) messengers were Mocked before thee; But their scoffers were hemmed in by the thing that they mocked. (AI-An'am:I0).

In the Verse above, the rhetorical function of the passive structure is related to the emphasis put on the event, rather than the agent, which is derived explicitly from the context.

(And they say Why was an angel not sent down to him." Had We sent down an angel, the matter would have been settled, and they would not have been reprieved).(AI-An'am:8)

They ask: 'Why has no angel been sent down to him? ' If We had sent down an angel, their fate would have been determined and they would never have been respited (AI-An'am:8).

Here, the agent is deleted for the purposes of avoiding redundancy, because the agent is mentioned in the Verse, with the active verb. Ellipsis is the non-expression of sentence elements whose meaning can be the addressee. It is the shared information that allows the addresser retrieved by to omit out things that have been said, or hinted at earlier. In grammatical analysis, ellipsis is a term used to refer to a sentence where, for reasons of economy, emphasis or style, a part of the structure has been omitted, which is recoverable from the scrutiny of the context. Ellipsis in the concept adopted throughout this study seems to have been discussed by Arab rhetoricians within either brevity or omission in its broadest sense, i.e. obligatory and optional. Arabs are highly interested in brevity which mostly involves the omission of superfluous linguistic items. Brevity is thought of as a mode of meaning expression in fewest linguistic items. It should be noted, however, that omission is not done haphazardly. Arab grammarians have put rules for ellipsis, for what can and cannot be omitted in an utterance in a particular context, otherwise unintelligibility or ambiguity will often loom indistinctly. Arab grammarians warn against using ellipsis unless it is necessary and/or understood. Ellipsis is considered as a mark of good style with a degree of reduction, compactness and connectedness. He alludes to the centrality of context in various elliptical phenomena since it is a decisive factor in the interpretation of all types of omission and without its clues the whole discourse will be nonsensical. In other words, the elided pieces of meaning must be recovered from the context or even inferred, otherwise communication would have never been intact or restored (Alduleimi, 2013).

Say: (Shall I take for myself a protector other than God, Originator of the heavens and the earth, and He feeds and is not fed?" Say, "I am instructed to be the first of those who submit." And do not be among the idolaters).(AI-An'am: 14).

Say: 'Should I take any but Allah for a guardian? He is the Originator of the heavens and the earth. He feeds and is not fed. 'Say: 'I was commanded to be the first to submit to Him. ' Do not be one of the idolaters(AI-An'am: 14).

A sentence in any language is a component of a speech or a written discourse that has a complete and independent meaning. Sentence segmentation refers to identifying sentences in an unstructured text. The process of sentence segmentation is a basic step for discourse analysis processing systems.

It is because; any text stream needs to be separated into coherent sentences in order to enable effective automatic analysis, such as information retrieval, summarization, understanding and translation.

In the example above, the connector /and/Waw" is used, which is the most ambiguous connector due to its mostly rhetorical use. In the Arabic rhetoric system, the meaning of "و " plays a great role of understanding consecutive 82 
sentences, and in turn determines the places of sentence endings. Historically, this problem was addressed long time ago, by a prominent Arabic linguist, "Abdel Qaher Al-Jorjany who died in 471 Higri". In his book "Dalael Al E'gaaz, he defines an approach, called "Fasl and Wasl", which means, "identifying segmentation places in a text". This approach identifies sentence ending places by understanding the meaning of the connector "و than other sentence connectors, because their functions as a sentence separator are evidently known (Khalifa, Feki, \& Farawila, 2011).

Say:(I fear, should I defy my Lord, the punishment of a tremendous Day).(Al-Anam:16). From whomsoever it is averted on that Day, He will have mercy on him; that is a clear triumph (AI-An'am: 16). The tendency of Arabic is to avoid the use of the passive voice as possible as one could do. However, this voice may tell us many things that another voice may not and all these are included within the stylistic feature of Arabic. Allah avoids ascribing the torture suffered by unbelievers to Him, while it is known that He is the source of it, while He ascribes explicitly the mercy to Himself.

Say: "What thing is more solemn in testimony?" Say, "God is Witness between you and me. This Quran was revealed to me, that I may warn you with it, and whomever it may reach. Do you indeed testify that there are other gods with God?" Say, "I myself do not testify." Say, "He is but One God, and I am innocent of your idolatry.(Al-anam :19).

'What thing is greatest in testimony?' Say: 'Allah is a witness between me and you. This Quran has been revealed to me in order that I can warn you and all whom it reaches. Do you indeed testify that there are gods other than Allah? ' Say: 'I do not testify! ' Say: 'He is only One God, and I am quit of that which you associate. '(AI-An'am: 19).

(Look how they lied to themselves. And what they invented deserted them.(Al-anam:27).

If you could see them when they are set before the Fire! They will say: 'Would that we could return! Then we would not belie the Verses of our Lord and would be believers. '(AI-An'am: 27).

In this Verse again, . Allah avoids ascribing the torture suffered by unbelievers to Him, while it is known that He is the source of it, while He ascribes explicitly the mercy to Himself.

(What they used to conceal before will become clear to them. And even if they were sent back, they would revert to what they were forbidden They are liars).(al-anam:28).

They are liars. Indeed, that which they concealed will appear to them. But if they were sent back, they would return to that which they have been forbidden. They are indeed liars. (AI-An'am: 28).

(Other messengers before you were rejected, but they endured rejection and persecution until Our help came to them. There can be no change to God's words. News of the Messengers has already reached you)(AlAnam:34). Messengers indeed were belied before you, yet they became patient with that which they were belied, and were hurt until our help came to them. There is none to alter the Words of Allah; and there has already came to you some news of the Messengers (AI-An'am: 34).

In the Verse above, the agent is deleted for a rhetorical function, that is related to the insignificance of those who belie the prophets (the unbelievers). Thus, their insignificance is expressed indirectly through the use of the passive.

(There is no animal on land, nor a bird flying with its wings, but are communities like you. We neglected nothing in the Scripture. Then to their Lord they will be gathered). (Al-Anam: 38).

There is no crawling creature on the earth, nor a bird that flies with its two wings, but they are nations like you. We have neglected nothing in the Book. They shall all be gathered before their Lord(AI-An'am: 38).

(Then, when they disregarded what they were reminded of, We opened for them the gates of all things. Until, when they delighted in what they were given, We seized them suddenly; and at once, they were in despair).( AIAn'am: 44).

And when they had forgotten that with which they have been admonished, We opened the gates of everything to them, until just as they were rejoicing in what they were given, We suddenly seized them and they were in utter despair(AI-An'am: 44).

(Thus the last remnant of the people who did wrong was cut off. And praise be to God, Lord of the Worlds) (AI-An'am: 45). 
As such the harm doers were annihilated. Praise be to Allah, Lord of the Worlds!(AI-An'am:45).

Here again, Allah avoids ascribing the torture suffered by unbelievers to Him, while it is known that He is the source of it, while He ascribes explicitly the mercy to Himself. From reciting the Quran to sitting at table, Muslims begin their actions by saying In the Name of God, the Compassionate, the Merciful. This sacred formula, whose author is God, is based firstly on the supreme name Allah, then on the two names al-Rahman and alRahim, both of which derive from Rahman, or mercy, a word which can also mean love, kindness, and compassion. God did not chose two names of wrath (ghadab) or even a balance between mercy and wrath, because with God there is no balance between mercy and wrath. Even wrath, from a certain point of view, is a kind of mercy for the believer, because it can purify his soul and help make him ready to enter Paradise.

(Say, "Have you considered? if God's punishment descended on you suddenly or gradually, would any be destroyed except the wrongdoing people?) (AI-An'am: 47).

Say: 'What do you see yourselves then, if the punishment of Allah overtook you suddenly or openly, would any be destroyed but the harmdoing nation?'(AI-An'am: 47).

(Say, "I do not say to you that I possess the treasuries of God, nor do I know the future, nor do I say to you that I am an angel. I only follow what is inspired to me." Say, "Are the blind and the seeing alike? Do you not think?)(AI-An'am: 50).

Say: 'I do not tell you that I have the treasuries of Allah or know the unseen, nor do I claim to be an angel. I follow only that which is revealed to me. ' Say: 'Are the blind and the seeing alike? Will you not think?(AIAn'am: 50).

(And warn with it those who fear to be gathered before their Lord-they have no protector or intercessor apart from Him-perhaps they will grow in piety).(AI-An'am: 51).

And warn with it those who fear to be brought before their Lord that they have no guardian or intercessor, other than Allah, in order that they are cautious(AI-An'am: 51).

(Thus We explain the revelations, and expose the path of the unrighteous). (AI-An'am: 55).

As such We make plain Our verses, so that the path of the wicked will be made clear(AI-An'am:55).

(Say, "I am forbidden from worshiping those you pray to besides God." Say, "I will not follow your desires; else I would be lost and not be of those guided).(AI-An'am: 56).

Say: 'I am forbidden to worship whom you call upon instead of Allah. ' Say: 'I will not yield to your wishes, for then I should have strayed and should not be of those guided. (AI-An'am: 56).

Say, "If I possessed what you seek me to hasten, the matter between you and me would have been settled. God is well aware of the unjust).(AI-An'am: 58).

Say: 'If what you seek to hasten were with me, the matter between you and me would be decided, and Allah knows very well the harm doers(AI-An'am: 58). '

It is He Who takes you by night, and He knows what you earn by day. Then He raises you up in it, until a fixed term is fulfilled. Then to Him is your return, then He will inform you of what you used to do).(AI-An'am: 60).

It is He who makes you to die by night, knowing what you have gained by day, and then resurrects you so that $\underline{\text { an }}$ ordained term is realized. To Him you shall return, and He will tell you of what you have been doing. $(\overline{A I-}$ An'am: 60).

(Then they are brought back to God, their True Master. Unquestionably, His is the judgment, and He is the Swiftest of reckoners). (AI-An'am: 62).

Then, they are returned to Allah their Guardian, the True. Surely, the judgment is for Him, He is the Swiftest of reckoners.(AI-An'am: 62).

(So leave alone those who take their religion for play and pastime, and whom the worldly life has deceived. But remind with it, lest a soul becomes damned on account of what it has earned. It has no helper or intercessor besides God. Even if it offers every equivalent, none will be accepted from it.

These are the ones who are delivered to perdition by their actions. They will have a drink of scalding water, and a painful punishment, because they used to disbelieve). (AI-An'am: 70).

Avoid those who take their religion as playing and an amusement and are seduced by the life of this world. Admonish them hereby lest a soul be taken by what it has gained, for it has no guardian or intercessor before 84 
Allah, and though it offers every ransom, it shall not be taken from it. Those are they who are taken for that which they earned. For them a drink of boiling water, a stern punishment for their disbelief(AI-An'am: 70).

(Say, "Shall we invoke besides God something that can neither benefit us nor harm us, and turn back on our heels after God has guided us; like someone seduced by the devils and confused on earth, who has friends calling him to guidance: 'Come to us'?" Say, "The guidance of God is the guidance, and we are commanded to surrender to the Lord of the Universe).(AI-An'am: 71).

Say: 'Are we to call, other than Allah, what can neither help nor harm us? Are we to be turned on our heels after Allah has guided us like him, who, being bewitched by devils, blunders aimlessly in the earth, although his friends call him to the guidance, (saying) 'Come to us! ' Say: 'The guidance of Allah is the Guidance. We are commanded to submit to the Lord of the Worlds,(AI-An'am: 71).

(It is He who created the heavens and the earth in truth. On the Day when He says: "Be," it will be. His saying is the truth, and His is the sovereignty on the Day when the trumpet is blown. The Knower of secrets and declarations. He is the Wise, the Expert).(AI-An'am: 73).

It was He who created the heavens and the earth in truth. On the Day when He says: 'Be, ' it shall be. His Word is the truth. His shall be the Kingdom on the Day when the Horn is blown. The Knower of the unseen and the visible, and He is the Wise, the Aware(AI-An'am: 73).

(Who does greater wrong than someone who invents falsehood against God, or says, "It was revealed to me," when nothing was revealed to him, or says, "I will reveal the like of what God revealed"? If only you could see the wrongdoers in the floods of death, as the angels with arms outstretched: "Give up your souls. Today you are being repaid with the torment of shame for having said about God other than the truth, and for being too proud to accept His revelations).(AI-An'am: 93).

Who is more harmful than he who invents a lie about Allah, or says: "It has been revealed to me," when nothing has been revealed to him? Or he who says: 'I will send down the like of what Allah has sent down! ' Would that you could see the harmdoers when death overwhelms them! With hands outstretched, the angels (will say): 'Yield up your souls. You shall be recompensed with a humiliating punishment this Day, for you have said of Allah what is untrue and you grew proud against His Verses (AI-An'am:93).

(Follow what was revealed to you from your Lord. There is no God but He. And turn away from the polytheists).(AI-An'am:106).

Therefore, follow what has been revealed to you from your Lord there is no God except Him, and avoid the idolaters(AI-An'am: 106).

(Shall I seek a judge other than God, when He is the One who revealed to you the Book, explained in detail?" Those to whom We gave the Book know that it is the truth revealed from your Lord. So do not be of those who doubt). (AI-An'am: l14).

Should I seek a judge other than Allah when it is He who has sent down the well distinguished Book for you? Those to whom We have given the Book know that it is the truth sent down from your Lord, so do not be among the doubters(AI-An'am: l14).

(So eat of that over which the Name of God was pronounced, if you indeed believe in His revelations). (AIAn'am: 118).

Eat then of that over which the Name of Allah has been mentioned(when slaughtered), if you truly believe in His Verses (AI-An'am: 118).

Is he who was dead, then We gave him life, and made for him a light by which he walks among the people, like he who is in total darkness, and cannot get out of it? Thus the doings of disbelievers are made to appear good to them)(122).

Is he who was dead whom We have revived and given a light with which he walks among people to be compared to him who blunders about in darkness from which he will never emerge? As such what the unbelievers have done appear decorated to them (AI-An'am: 122).

(When a sign comes to them, they say, "We will not believe unless we are given the like of what was given to God's messengers." God knows best where to place His message. Humiliation from God and severe torment will afflict the criminals for their scheming).(124). 
When a sign came to them they said: 'We will not believe in it unless we are given that which the Messengers of Allah have been given. ' But Allah knows best where to place His Message. Humiliation with Allah shall befall the sinners as well as a terrible punishment for what they devised(AI-An'am: 124).

(And they say, "These animals and crops are restricted; none may eat them except those we permit," by their claims, and animals whose backs are forbidden, and animals over which they do not pronounce the name of God-fabricating lies against Him. He will repay them for what they used to invent). (138).

They say: 'These cattle, and these crops are forbidden. None can eat of them except those whom we permit' so they claim 'and cattle whose backs are forbidden, and others over which they do not pronounce the Name of Allah. ' As such fabricating lies against Him. He will recompense them for their invented lies(AI-An'am138).

( Say, "In what was revealed to me, I find nothing forbidden to a consumer who eats it, except carrion, or spilled blood, or the flesh of swine-because it is impure-or a sinful offering dedicated to other than God. But if someone is compelled by necessity, without being deliberate or malicious-your Lord is Forgiving and Merciful).(145).

Say: 'I find nothing in what has been revealed to me that forbids any one to eat of any food except the dead, running blood, and the flesh of swine for these are unclean and that which has been hallowed in its slaughter to other than Allah. But whoever is constrained to eat of any of these, not intending to sin or transgress, then your Lord is Forgiving, the Most Merciful(AI-An'am: 145).

(If they accuse you of lying, say, "Your Lord is Possessor of infinite mercy, but His wrath cannot be averted from the guilty people).(147).

If they belie you, say: 'Your Lord is the Owner of all Encompassing Mercy, but His Might cannot be withheld from the nation, the evildoers.(AI-An'am: 147).

(Lest you say, "The Scripture was revealed to two parties before us, and we were unaware of their teachings). (156).

lest you should say: 'The Book was sent down only to two parties before us; we are inattentive to their study. (AIAn'am: 156).

(Or lest you say, "Had the Scripture been revealed to us, we would have been better guided than they." Clarification has come to you from your Lord, and guidance, and mercy. Who then does greater wrong than he who gives the lie to God's messages, and turns away from them? We will repay those who turn away from Our messages with the worst kind of punishment, because of their turning away). (157)..

Or (you say), 'Had the Book been sent down to us, we would have been better guided than they.' Indeed a clear sign has now come to you from your Lord; a guidance and a mercy. And who is more harmful than he who belies the Viruses of Allah and turns away from them! We shall recompense those who turn away from Our Viruses with an evil punishment for their turning away(AI-An'am: 157).

(Whoever comes up with a good deed will have ten times its like; and whoever comes up with an evil deed will be repaid only with its equivalent-they will not be wronged.(160).

He who brings a good deed shall have tenfold of its like, but he who brings a sin shall be recompensed only for its like. None shall be wronged(AI-An'am: 160).

(No associate has He. Thus I am commanded, and I am the first of those who submit).(163).

He has no partner, with that I am commanded, and I am the first of the submitters (Muslims)(AI-An'am: 163).

\section{Agentive Passive Sentences}

According to researchers (Areibi, 2013), the use of the agent less passive is an excellent way to solve a problem that most languages encounter: the formation of a sentence without the logical subject. The agentive passive voice is used since there is an inclination in Arabic to avoid subject less sentences with transitive verbs. Intransitive verbs, however, are often used in subjectless sentences as will be shown in the examples from the Quran below. As pointed out, some passive sentences that occur in the Holy Quran upon which this study is based have an overtly expressed agent.

This, of course, contradicts the belief which is commonly held by Arab grammarians that Arabic passive sentences do not have an expressed agent. This, of course, explains why passive sentences are called? al-mabni lil-majhu:1, that is sentences whose agent is unknown. There is agreement among early and modern grammarians 
that the mabni lil-majhūl results in the syntactic deletion of the subject / actor and its substitution by the object / affected participant, which not only occupies its position but also assumes all diacritic features a subject usually takes. However, in the Holy Qur'an it is not infrequent to find agentive / long passive construction :

\section{Conditionals / Protasis}

The ordinary form of conditional sentence in Arabic includes just two parts: protasis clause and apodosis clause; However, it might be possible to extend the number of the first part by joining two or more protasis clause and putting them together, with or without conjunctions (Gwynne, 2014).

Passive constructions may occur in the conditional subordinate (if) clause as illustrated in the following Verses:

(What they used to conceal before will become clear to them. And even if they were sent back, they would revert to what they were forbidden. They are liars.(28).

But if they were returned, they would certainly relapse to the things they were forbidden, for they are indeed liars.(Al-An'aam:28) The passive construction in the above Verse in the subordinate clause immediately after the subordinator(IF) as conditional particle.

All natural languages are assumed to have at least some types of conditional sentences. However, due to their complexity, many models of grammar are unable to make provision for them, tending to keep the discussion of conditionals on a trivial level. What constitutes a conditional construction in a given language still has no reasonable theoretical answer in linguistics today, and conditionals continue to be one of the least explored areas of linguistic research. Nevertheless, present-day linguistics is witnessing a growing interest in the investigation of conditionals, as researchers do begin to recognize them as more than just a linguistic phenomenon, but also as a key to certain mysteries of human speech and thought activities. In other words, focus is gradually beginning to shift from focusing mostly on the form of conditionals to attempting a more in-depth understanding of also their meaning. Thus, the semantic interpretation of conditionals should be an integral part of their description (Jalonen, 2017).

(And they say, "If only a sign could come down to him from his Lord." Say, "God is Able to send down a sign, but most of them do not know). (37).

They ask: 'Why has no sign been sent down to him from his Lord? ' Say: 'Allah is Able to send down a sign. ' But most of them do not know(AI-An'am: 37).

Rejected were the Messengers before thee: with patience and constancy they bore their rejection and their persecution until our aid did reach them. ( Al- An؟am :34) It is not important for the spectators to know who brought them the good news. The most important is the action itself(AI-An'am: 34)..

Agent - focusing. A correlate of the morph syntactic changes to the verb in Modern Standard Arabic is a pragmatic function "agent defocusing" (Shibantani, 1985:830, Mayhill, 1997). Agent defocusing in Modern Standard Arabic occurs in two ways (i) defocusing the agent to the full extent, by deleting it, or (ii) defocusing it to some degree i.e. by allowing it to show up in the prepositional phrase in the rheumatic position. (Agentive /long passive). Nevertheless, agent - defocusing, contrary to common beliefs, should not be understood to be a form of downgrading the agent by moving it to the end position. Actually, one of the motivations for using the passive construction in Arabic is to assign new to an agent noun root. The following example illustrated this point (Nofal, 2011, 165).

They say "Why is not a sign sent down to him from his lord!" (Al-An-am : 37)

The agent "from his lord" is represented as relegated, but in this specific position it gets more importance than if it were in invited position.

\section{Conclusion}

This study sought to investigate the syntactic and the semantic/ stylistic functions of the passive constructions in the Holy Qur'an. Since the study depends not only on syntax, but also on semantics and interpretation, we dare say that the passive constructions that cannot be parsed, i.e., they do not have syntactic functions, actually do have such functions. Relative clauses, for example, function as post modifiers to the head nouns, "kana" and its sisters in addition to" Inna" and its sisters do have passive constructions as their predicate. Moreover, passive constructions may function as complement of oath and complement of vocative (Nofal, 2011). The Holy Qur'an, as is illustrated through the analysis of Surat Al-An'am, has agentive and agentless passive constructions. But agentless passive constructions remarkably outnumber agentive ones. 
Although Arabic has only agentless passive sentences, some passive sentences have explicitly stated agents. Such sentences may have been imposed in Arabic by the influence of western languages. However, this issue is different in the Holy Qur'an where the agent is explicit or overt for certain purpose intended by His Al- mighty Allah. For future research, the rhetorical as well as the stylistic features of Passivation in the holy Quran can be examined in depth, in addition to the various functions they serve in the context of the various of the holy Quran.

\section{References}

Abdelaal, N., \& Md Rashid, S. (2016). Grammar-Related Semantic Losses in the Translation of the Holy Quran, with Special Reference to Surat Al A'araf (The Heights). SAGE Open, 6(3).

Al-duleimi, A. (2013). Some Functions of Ellipsis in Religious Texts. European Scientific Journal, ESJ, 9(19), 128-140.

Al-Shawwa, A. (2007). The Passive Voice In Arabic. Lisan Al-Arab Publishers, Damascus.

Alsuhaibani, S. (2012). The verbal sentence in written Arabic. Thesis, University of Exeter.

Areibi, M. (2013). Semantic and Syntactic Investigation of the Passive Voice in English and Arabic with Reference to Text Typology. thesis, The University of Benghazi.

Ayyat, A., Sultan, F., \& Yasin, M. (2016). A Minimalist Approach to Agentive Passive in Standard Arabic.International Journal of Recent Research in Social Sciences and Humanities (IJRRSSH), 3(4), 149-157.

Durakovi, E. (2007). RHETORICAL TWIST IN THE QURAN.Jordan Journal of Islamic Studies, 4(1), 1-7.

Farghal, M., \& Al-Shorafat, M. (1996). The Translation of English Passives into Arabic: An Empirical Perspective. Target. International Journal of Translation Studies, 8(1), 97-118.

Gadalla, H. (2010). Syntactic Classes of the Arabic Passive Participle: And how they should be rendered into English. Babel, 56(1), 1-18.

Gwynne, R. (2014). Logic, Rhetoric and Legal Reasoning in the Qur'an: God's Arguments. Routledge.

Jabbari, M., \& Kafipour, R. (2011). Long passive formation in English and Arabic A pragmatic approach. European Journal of Social Sciences, 26(2), 193-200.

Jalonen, J. (2017). Conditional Constructions in Damascus Arabic: Form and meaning. thesis, Uppsala university.

Khalifa, I., Feki, Z., \& Farawila, A. (2011). Arabic Discourse Segmentation Based on Rhetorical Methods. Int. J. Electric Comput. Sci, 11(1), 10-15.

Laks, L. (2013). Passive formation in Palestinian and Standard Arabic: Lexical vs. syntactic operations. Word Structure, 6(2), 156-180.

Maalej, Z. (1999). Passives in Modern Standard and Tunisian Arabic. Matériaux Arabes et SudarabiquesGellas, 9, 51-76.

Mirdehghan, M., Zahedi, K., \& Nasiri, M. (2012). Iltifat, Grammatical Person Shift and Cohesion in the Holy Quran. Global Journal of Human-Social Science Research, 12(2), Available at :https://socialscienceresearch.org/index.php/GJHSS/article/view/279>. Date accessed: 26 jan. 2018.

Nofal, K. (2011). Passive Constructions in the Holy Qur'an. international Journal of Social Sciences and Education, 1(4), 699-721.

Nofal, K. (2011). Passive Voice as an Inimitable Linguistic Phenomenon in the Holy Qur'an. International Journal of Business and Social Science, 2(18), 148-168.

Nofal, K. (2013). Semantic Functions of Passive Constructions in the Holy Qur'an. Theory and Practice in Language Studies, 3(6), 894-902.

Ryding, K. C. (2005). A reference grammar of modern standard Arabic. Cambridge university press.

Shormani, M. (2017). Person Approach to Personal Passive in Standard Arabic. AL Lisaniyyat, 23, 85-134. 